\title{
Quarterly Management Document FY20, 1st Quarter, Multi-pass Hybrid Laser Arc Welding of Alloy $740 \mathrm{H}$
}

Thomas M Lillo

January 2020

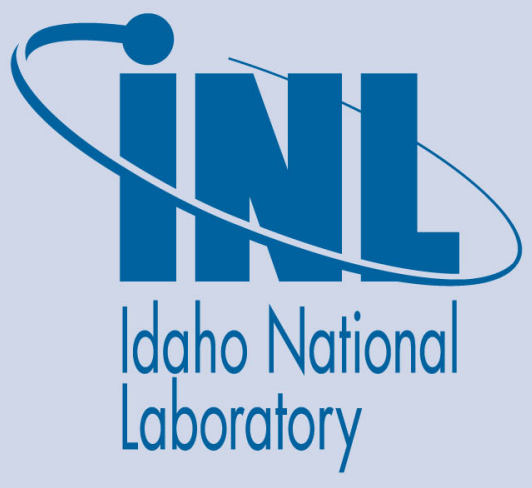

The INL is a U.S. Department of Energy National Laboratory operated by Battelle Energy Alliance 


\section{Quarterly Management Document FY20, 1st Quarter, Multi-pass Hybrid Laser Arc Welding of Alloy $740 \mathrm{H}$}

Thomas M Lillo

January 2020

Idaho National Laboratory Idaho Falls, Idaho 83415

http://www.inl.gov

Prepared for the U.S. Department of Energy Office of Fossil Energy Under DOE Idaho Operations Office

Contract DE-AC07-05ID14517 
Quarterly Management Document - FY20, ${ }^{\text {st }}$ Quarter, Multi-pass Hybrid Laser Arc Welding of Alloy $740 \mathrm{H}$

Document \# INL/EXT-20-57193

\begin{tabular}{|l|l|l|l|l|}
\hline $\begin{array}{l}\text { WBS Element } \\
\text { C.B.75.AA.01.01.01 }\end{array}$ & $\begin{array}{l}\text { Project Title } \\
\text { Multi-pass Hybrid Laser Arc } \\
\text { Welding of Alloy 740H }\end{array}$ & $\begin{array}{l}\text { Contract } \\
\text { Number } \\
\text { ????? }\end{array}$ & $\begin{array}{l}\text { Contract } \\
\text { Start } \\
\mathbf{1 0 / 0 1 / 1 9}\end{array}$ & $\begin{array}{l}\text { Contract } \\
\text { End } \\
\mathbf{0 9 / 3 0 / 2 0 2 2}\end{array}$ \\
\hline $\begin{array}{l}\text { Performer Name and Address } \\
\text { Thomas Lillo }\end{array}$ & $\begin{array}{l}\text { Principal Investigator(s) } \\
\text { Idaho National Laboratory }\end{array}$ \\
$\begin{array}{l}\text { P.O. Box 1625 } \\
\text { Idaho Falls, ID 83415 }\end{array}$ & & \\
\hline
\end{tabular}

\section{BUDGET AND COST REPORT}

\begin{tabular}{|c|c|c|c|c|c|c|c|c|c|c|c|c|}
\hline Prior Yea & Func & $(\$ K)$ & & $\mathbf{0}$ & & & & & & & & \\
\hline $\begin{array}{l}\text { Total Cur } \\
\text { Commitm }\end{array}$ & $\begin{array}{l}\text { ent Y } \\
\text { nt (\$1 }\end{array}$ & & & 859 & & & & & & & & \\
\hline $\begin{array}{l}\text { Projected } \\
\text { (\$K) }\end{array}$ & Curre & Yea & Costs & 435 & & & & & & & & \\
\hline & $\mathbf{O}$ & $\mathbf{N}$ & D & $\mathbf{J}$ & $\mathbf{F}$ & $\mathbf{M}$ & $\mathbf{A}$ & M & $\mathbf{J}$ & $\mathbf{J}$ & $\mathbf{A}$ & $\mathbf{S}$ \\
\hline $\begin{array}{l}\text { Monthly } \\
\text { Planned } \\
\text { Costs }\end{array}$ & 4 & 10 & 10 & & & & & & & & & \\
\hline $\begin{array}{l}\text { Actual } \\
\text { Monthly } \\
\text { Costs }\end{array}$ & 2 & 13 & 7 & & & & & & & & & \\
\hline $\begin{array}{l}\text { Monthly } \\
\text { Variance }\end{array}$ & 2 & -3 & 3 & & & & & & & & & \\
\hline $\begin{array}{l}\text { Total } \\
\text { costs - } \\
\text { planned }\end{array}$ & 4 & 14 & 24 & & & & & & & & & \\
\hline $\begin{array}{l}\text { Total } \\
\text { costs - } \\
\text { actual }\end{array}$ & 2 & 15 & 22 & & & & & & & & & \\
\hline
\end{tabular}


MILESTONE REPORT

\begin{tabular}{|c|l|l|l|l|}
\hline $\begin{array}{c}\text { Milestone } \\
\text { Designation }\end{array}$ & \multicolumn{1}{|c|}{ Milestone Description } & Due Date & $\begin{array}{c}\text { Revised } \\
\text { Due Date }\end{array}$ & $\begin{array}{c}\text { Completion } \\
\text { Date }\end{array}$ \\
\hline Task 1.A & $\begin{array}{l}\text { Purchase of Laser Wobble Head by } \\
\text { PSU }\end{array}$ & $12 / 31 / 2019$ & $3 / 15 / 2020$ & \\
\hline Task 1.B & $\begin{array}{l}\text { Deep Penetration Land Welding } \\
\text { Development }\end{array}$ & $09 / 30 / 2020$ & & \\
\hline Task 1.C & Modeling of Deep Penetration Welding & $9 / 30 / 2020$ & & \\
\hline Task 2.A & $\begin{array}{l}\text { Purchase and installation of laser } \\
\text { wobble head by INL }\end{array}$ & $12 / 30 / 2020$ & $3 / 15 / 2020$ & \\
\hline Task 2.B & $\begin{array}{l}\text { Single pass bead-on-plate welds with } \\
\text { microstructure characterization }\end{array}$ & $06 / 30 / 2020$ & & \\
\hline Task 2.C & Multi-pass HLA welds & $09 / 30 / 2021$ & & \\
\hline Task 2.D & Stress Relief Cracking Evaluation & $9 / 30 / 2021$ & & \\
\hline Task 2.E & $\begin{array}{l}\text { Mechanical Properties and Creep } \\
\text { Testing }\end{array}$ & $9 / 30 / 2021$ & & \\
\hline Task 2.F & Radiograph Welds for Defects & $3 / 31 / 2021$ & & \\
\hline Task 3.A & $\begin{array}{l}\text { Complete 3" thick weld using 12 kW } \\
\text { laser }\end{array}$ & $6 / 30 / 2022$ & & \\
\hline Task 3.B & $\begin{array}{l}\text { Modeling and Simulation of 3" thick } \\
\text { Weld }\end{array}$ & $6 / 30 / 2022$ & & \\
\hline Task 3.C & $\begin{array}{l}\text { Complete 3" thick weld using 4 kW } \\
\text { laser }\end{array}$ & $6 / 30 / 2022$ & & \\
\hline Task 3.D & $\begin{array}{l}\text { Characterization - Microstructure \& } \\
\text { Mechanical properties of 3" thick weld }\end{array}$ & $9 / 30 / 2022$ & & \\
\hline Task 3.E & $\begin{array}{l}\text { Stress Relief Cracking Evaluation of 3" } \\
\text { thick weld }\end{array}$ & $9 / 30 / 2022$ & & \\
\hline Task 3.F & Radiograph 3" thick welds for defects & $6 / 30 / 2022$ & & \\
\hline
\end{tabular}




\section{Task 1.A, Purchase of Laser Wobble Head by PSU}

The subcontract with PSU was finally implemented the last week of December 2019 and a quote for the wobblehead was obtained. Procurement paperwork has been started and the purchase is expected to be made in January 2020. The wobblehead is expected to be received and installed by $3 / 1 / 2020$. Therefore the expected completion date for this task has been revised to $3 / 15 / 2020$.

\section{Task 1.B, Deep Penetration Land Welding Development}

Since the subcontract with PSU finalized at the end of December 2019, no work on this task was performed during the first quarter of FY20. Work will commence as soon as Task 1.A is complete. Progress is expected to be rapid once the wobblehead is installed and the delayed start of this task is not expected to adversely affect the expected completion date.

\section{Task 1.C, Modeling of Deep Penetration Welding}

Delays on implementation of the subcontract with PSU until the end of December 2019 has prevented any progress on this task. However, a search for a student was initiated who will work on this task. The delayed start is not expected to adversely affect the expected completion date for this task.

\section{Task 2.A, Purchase and installation of laser wobble head by INL}

The wobblehead for the INL system was spec'd out with input from Todd Palmer at PSU. A quote was obtained from IPG Photonics, Inc., and the unit was ordered. Expected delivery date is $2 / 27 / 2020$. This has delayed work on this task and requires the expected completion date to be date for this task to be changed to 3/15/2020. While waiting for the wobblehead to arrive, work was proceeded on designing the integration of the wobblehead into the current INL hybrid laser welding system. This will ensure that once the wobblehead arrives it can quickly be attached to the system and work on Task 2.B, below, can commence.

\section{Task 2.B, Single pass bead-on-plate welds with microstructure characterization}

This task cannot start until the laser wobblehead arrives and is installed on the hybrid laser welding system. The delayed start is not expected to adversely affect the expected completion date as tiem can be made up quickly. 


\section{Task 2.C, Multi-pass HLA welds}

Task is not scheduled to start yet.

\section{ISSUES}

Although there were significant delays in the implementation of the PSU contract, they are not expected to significantly impact the completion date of the various tasks which will be accelerated somewhat to get the project back on schedule. As such, there are no apparent issues with schedule, scope or budget of the project at this time.

\begin{tabular}{|l|l|}
\hline Report Prepared By & Date \\
\hline Thomas M. Lillo & $01 / 24 / 2020$ \\
\hline
\end{tabular}

